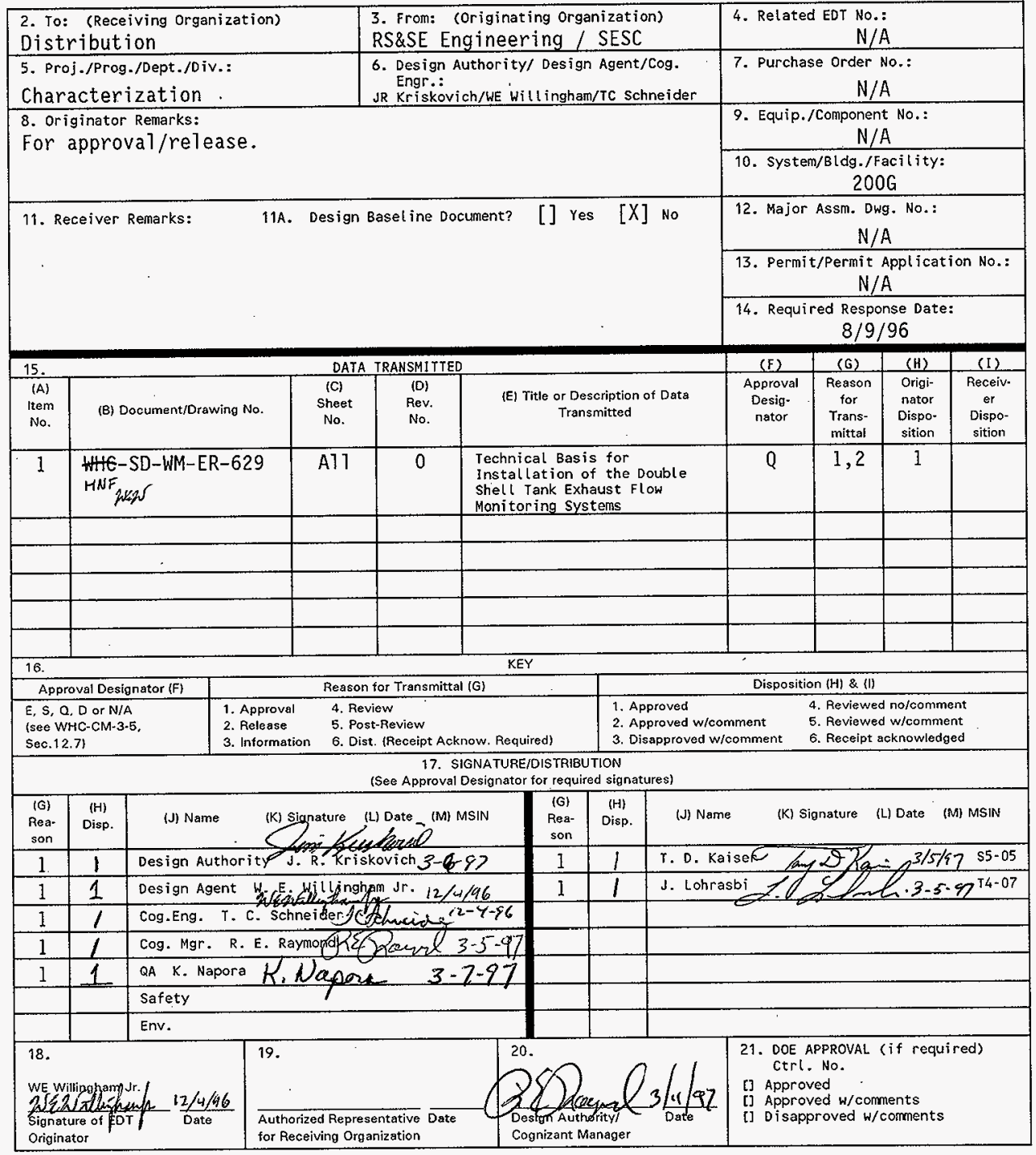




\title{
Technical Basis for Installation of the Double Shell Tank Exhaust Flow Monitoring Systems
}

W. E. Willingham Jr.

SGN Eurisys Services Corporation, Richland, WA 99352

U.S. Department of Energy Contract DE-AC06-96RL13200

\author{
EDT/ECN: 618891 \\ Org Code: $\$ 1200$ \\ UC: 2070 \\ B\&R Code: EW3120072 \\ Charge Code: N2051 \\ Total Pages: 5
}

Key Words: technical basis, flow monitoring, ventilation, double shell tanks, watch 1ist, flammable gas

Abstract: This document presents the technical bases for installation of flow meters on the ventilation exhaust ducts of the flammable gas watch list double shell tanks (24I-AN-103, 241-AN-104, 241-AN-105, 241-AN-107, 241-AW-101 and 241-SY-103), the saltwell receiver tanks (241-AN-101 and 241-SY-102) and the cross-site receiver tank (241-AP-104).

TRADEMARK DISCLAIMER. Reference herein to any specific commercial product, process, or service by trade name, trademark, manufacturer, or otherwise, does not necessarily constitute or imply its endorsement, recommendation, or favoring by the United States Govermment or any agency thereof or its contractors or subcontractors.

Printed in the United States of America. To obtain copies of this document, contact: WHC/BCS Document Control Services, P.O. Box 1970, Mailstop H6-08, Richland WA 99352, Phone (509) 372-2420; Fax (509) 376-4989
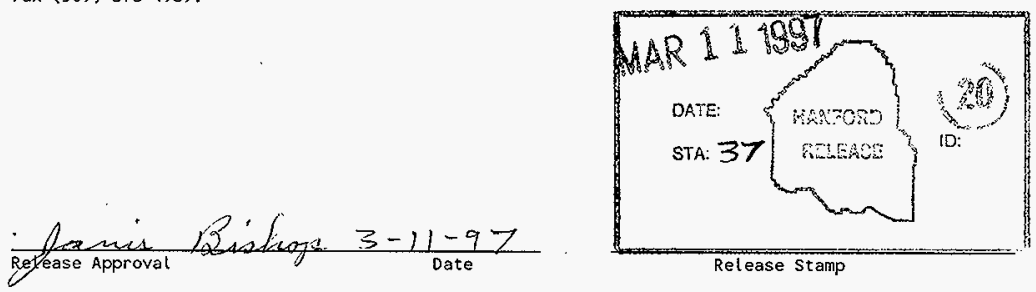

Release stamp

\section{Approved for Public Release}


HNF-SD-WM-ER-629, REV. 0

Page 1 of 4

\section{TECHNICAL BASIS FOR INSTALLATION OF THE DOUBLE SHELL. TANK EXHAUST FLOW MONITORING SYSTEMS}

\subsection{TECHNICAL BASES}

This document presents the technical bases for installation of flow meters on the ventilation exhaust ducts of the flammable gas watch 1 ist double she11 tanks (241-AN-103, 241-AN-104, 241-AN-105, 241-AN-107, 241-AW-101 and 241-SY-103), the saltwell receiver tanks (241-AN-101 and 241-SY-102) and the cross-site receiver tank (241-AP-104). Two flow meters will be installed per tank. The low range will cover 40-400 scfm for normal operations and the high range meter will cover 300-3000 scfm for measuring flow during gas release events (Wilkins 1993).

These flow meters are being installed for the following reasons:

- The flow meters for the flammable gas double shell tanks were committed to RL and to the Defense Nuclear Facility Safety Board (DNFSB) as a result of the last two flammable gas releases in tank $\mathrm{AN}-105$, which were in the 50\% LFL range (Minteer 1996a), (Minteer 1996b).

- Flow monitoring, in conjunction with hydrogen monitoring equipment already installed, will allow for determination of the overall hydrogen generation and release rates. This information is needed to perform the safety analysis to close the flammable gas USQ, to close the Safety Issue, and to ultimately remove these tanks from the Flammable Gas Watch List.

- Delay in characterizing flammable gas release rates could delay closure of the USQ/Flammable Gas Safety Issue.

- Manual flow measurements have proven to be nonrepeatable and unreliable. Potential unsafe tank conditions exist with inadequate flow, since the ventilation flow provides a dilution of the flammable gases released into the tank vapor space.

- This work pertains to a portion of WBS 1N21D4 - Monitoring and Mitigation of Flammable Gas Tanks and WBS 2N21DC - Flammable Gas Safety Issues. This work is to be performed in order to comply with draft Double She7l Tank Interim Operational Safety Requirements, WHC-SD-WM-OSR-16 Rev. OB., Section 5.29 which states in part:

"Administrative controls shall be established to manage flammable gas hazards related to the WASTE storage tanks that generate flammable gasses. The administrative controls shall include not only tanks in which WASTE exhibits the potential to retain flammable gasses and release them episodically but aiso tanks in which WASTE generates and releases flammable gasses chronically. The program elements shall include as a minimum:

a. Flammable gas generation rates and ventilation effectiveness, as well as tank physical parameter information (e.g. WASTE Tevel, pressure, temperature), shall be evaluated and compared with established criteria to (1) assign the proper NFPA classifications and (2) identify 
tanks in which WASTE exhibits the potential to retain flammable gases and release them episodically and thus comprise the Flammable Gas Watch List."

- Eventually, an administrative control on the exhaust flow rates from each of these tanks will most likely be developed, as was done for 241-SY-101, as part of the safety assessments for these tanks.

- These flow meters are part of the Safety Issue Resolution Multi-Year Program Plan for FY-97.

- Flow controllers are being installed on the inlets to these tanks. The flow meters installed on the exhaust will be needed during operations to keep flow balanced between tanks, considering the unfiltered inleakage through pump pits, etc.

\subsection{SAFETY CLASS}

The Double Shell Tank and Aging Waste Facility Primary Tank Ventilation Systems are identified as safety-class systems (Hicks 1996). The only Supporting Structure, system or component identified is electrical power. This flow monitoring system will be used to provide information on $1 y$ and will not be utilized for automatic control of the ventilation system. A specific flow rate is not a critical parameter identified in the authorization basis, nor is it identified in the BIO or FSAR.

The ventilation system requirements are 1.) that the systems be operable (WHC 1996a) and 2.) maintain a specified negative pressure in the vapor spaces of the tanks (Hicks 1996). Pressure sensors are used to verify these operational requirements. There are presentiy no safety requirements for ventilation flow measurements.

For the reasons stated above the system will be designated as a General Service system as determined by the methodology of WHC-CM-4-46, Safety Analysis Manual, section 9.0. However, the flame arresters in the pressure sensing lines provide defense-in-depth to existing Safety Class equipment. For this reason the flame arresters will be added to the Tanks Farms Safety Equipment List. The flame arresters must be approved per NFPA for use with Group B gases (hydrogen).

The system design was presented to the Flammable Gas Equipment Advisory Board on November 21, 1996. It was determined that the equipment does comply with WHC-SD-WM-JCO-007, Rev. OA and Standing Order 96-36, Rev. 1, and is acceptable for use for measuring flow in air streams that require ICS 2 ignition controls (Scaief III, 1996). 
HNF-SD-WM-ER-629, REV. 0

Page 3 of 4

\subsection{BIBLIOGRAPHY}

Grigsby, J.M. and Leach, C.E., 1996, Flammab7e Gas/S7urry Growth Unreviewed Safety Question: Justification for Continued Operation for the Tank Farms at the Hanford Site, WHC-SD-WM-JC0-007, Rev. O, G \& P Consulting, Inc. and Westinghouse Hanford Company, Richland, Washington.

Groth, B.D., 1995a, Design Requirements Document - Primary Ventilation Flow Monitoring for DSTs on the Hydrogen Watch List, WHC-SD-WM-DRD-003, Rev. 0, Westinghouse Hanford Company, Richland, Washington.

Groth, B.D., 1995b, Task Plan for Design and Installation of Primary Exhaust Ventilation Flow Monitoring in Double Shel7 Hydrogen Watch List Tanks, WHC-SD-WM-ETP-156, Rev. 0, Westinghouse Hanford Company, Richland, Washington.

Hertelendy, N.A., 1995a, Engineering Study and Conceptual Design Report for Primary Ventilation Duct Flow Monitoring, WHC-SD-WM-CDR-026, Rev. 0, Westinghouse Hanford Company, Richland, Washington.

Hertelendy, N.A., 1995b, Task Plan for the Selection and Evaluation of Flow Monitoring Instrumentation to be Used on the Primary Exhaust Ventilation in Double Shell Hydrogen Watch List Tanks, WHC-SD-WM-ETP-178, Rev. 0, Westinghouse Hanford Company, Richland, Washington.

Hicks, D.F., 1996, Tank Waste Remediation System Safety Structures, Systems, and Components: Requirements and Characteristics, WHC-SD-WM-RD-057, Rev. 0, Westinghouse Hanford Company, Richland, Washington.

Minteer, D.J., 1996a, Waste Tank 241-AN-105 Gas Re7ease Response Recommendations, WHC-SD-WM-ER-524, Rev. 0, Westinghouse Hanford Company, Richland, Washington. (Transmitted to RL by WHC letter 9650393.)

Minteer, D.J., 1996b, Status of P7anned Activities in Response to AN-105 Gas Release, (DSI to J.W. Lentsch, June 21), Westinghouse Hanford Company, Richland, Washington. (Transmitted to RL by WHC Tetter 9652960.)

Scaief, C.C. III, 1996, F7ammable Gas Equipment. Advisory Board Interpretation/Recommendation Report, FGEAB-97-012, Lockheed Martin Hanford Company, Richland, Washington.

Schlosser, R.L., 1996, Safety Basis for Activities in Double Shell Flammab7e Gas Watch7ist Tanks, WHC-SD-WM-SARR-002, Rev. 1, Westinghouse Hanford Company, Richland, Washington.

WHC, 1996a, Tank Waste Remediation System "Technical Safety Requirements", WHC-SD-WM-TSR-006, Rev. E, Draft, Westinghouse Hanford Company, Richiand, Washington.

WHC, 1996b, Tank Waste Remediation System Functions and Requirements Document, WHC-SD-WM-FRD-020, Rev. 1, Westinghouse Hanford Company, Richland, Washington. 
Wilkins, N.E., 1993, Evaluation of June 1993 Tank 241-SY-101 Gas Release Event, WHC-SD-WM-PE-050, Rev. 0, Westinghouse Hanford Company, Richland, Washington.

Willingham Jr., W.E., 1996a, Test Plan for Evaluation of Primary Exhaust Ventilation Flow Meters for Double Shel7 Hydrogen Watch List Tanks, WHC-SD-WM-TP-441, Rev. 0, ICF Kaiser Hanford Company, Richland, Washington.

Willingham Jr., W.E., 1996b, Test Report of Evaluation of Primary Exhaust Ventilation Flow Meters for Double Shell Hydrogen Watch List Tanks, WHC-SD-WM-TRP-254, Rev. 0, ICF Kaiser Hanford Company, Richland, Washington.

Willingham Jr., W.E., 1997, Double She77 Tank Primary Ventilation Exhaust Flow Monitor System Design Description, HNF-SD-WM-SDD-074, Rev. 0, SGN Eurisys Services Corporation, Richland, Washington. 


\begin{tabular}{|c|c|c|c|c|c|}
\hline \multicolumn{6}{|c|}{ DISTRIBUTION SHEET } \\
\hline \multirow{2}{*}{$\begin{array}{l}\text { To } \\
\text { Distribution }\end{array}$} & \multirow{2}{*}{\multicolumn{3}{|c|}{$\begin{array}{l}\text { From } \\
\text { W. E. Willingham Jr. }\end{array}$}} & \multicolumn{2}{|c|}{ Page 1 of 1} \\
\hline & & & & \multicolumn{2}{|c|}{ Date $3 / 7 / 97$} \\
\hline \multirow{2}{*}{\multicolumn{4}{|c|}{$\begin{array}{l}\text { Project Title/ Work Order } \\
\text { Characterization }\end{array}$}} & \multicolumn{2}{|c|}{ EDT No. 618891} \\
\hline & & & & \multicolumn{2}{|c|}{ ECN No. } \\
\hline Name & MSIN & $\begin{array}{l}\text { Text } \\
\text { With All } \\
\text { Attach. }\end{array}$ & Text Only & $\begin{array}{l}\text { Attach./ } \\
\text { Appendix } \\
\text { Only }\end{array}$ & $\begin{array}{l}\text { EDT/ECN } \\
\text { Only }\end{array}$ \\
\hline $\begin{array}{l}\text { W. E. Willingham Jr. } \\
\text { C. E. Hanson } \\
\text { T. C. Schneider } \\
\text { D. D. Tate } \\
\text { D. W. Crass } \\
\text { K. Napora } \\
\text { C. C. Scaief III } \\
\text { J. R. Kriskovich } \\
\text { R. E. Raymond } \\
\text { J. Lohrasbi } \\
\text { T. D. Kaiser } \\
\text { R. S. Nicholson } \\
\text { K. A. White } \\
\text { M. J. Sutey } \\
\text { Central Files }\end{array}$ & $\begin{array}{l}H 6-11 \\
S 7-12 \\
\text { L6-37 } \\
\text { L6-37 } \\
H 5-68 \\
\text { L6-35 } \\
\text { R1-56 } \\
\text { R1-56 } \\
\text { S7-12 } \\
\text { S5-05 } \\
\text { T4-07 } \\
\text { S5-05 } \\
\text { S5-09 } \\
\text { T4 } 4-08 \\
\text { A3-88 }\end{array}$ & $\begin{array}{l}x \\
X \\
x \\
X \\
X \\
x \\
X \\
X \\
X \\
X \\
X \\
X \\
X \\
x \\
x\end{array}$ & . & . & \\
\hline
\end{tabular}

